\title{
Retinoblastoma cT2b TNM Finding v7
}

National Cancer Institute

\section{Source}

National Cancer Institute. Retinoblastoma cT2b TNM Finding v7. NCI Thesaurus. Code C88760.

Massive vitreous and/or subretinal seeding is present, defined as diffuse clumps or "snowballs" of tumor cells. (from AJCC 7th Ed.) 